\title{
EARLY AGE CORROSION OF MILD STEEL IN AGGRESSIVE MEDIA
}

\author{
A. U. OZTURK, E. GUCUYEN R. T. ERDEM, S. SEKER
}

Department of Civil Engineering, Celal Bayar University, Manisa, Turkey

Effect of exposure time, section type and solution concentration on mild steel early age corrosion was studied. Steel specimens section types were box, tube and corner. They were subjected to $3.5 \% ; 5.0 \%$ and $7.0 \% \mathrm{NaCl}$ solutions. It was established that solution concentration effects the corrosion until reaching the saturation value.

Keywords: corrosion, mild steel, section type, $\mathrm{NaCl}$.

Experimental analyzes for various purposes have become significant in studies for the last couple of decades. Engineering problems of combining cities by long span bridges or constructing the highest skyscrapers in the world have two different sides. The problems seem to be such a naked structural analysis, which can be solved with engineering analysis programs by using computers of great capacities.

In fact, these problems are not as the same as they seem to be. They have another side which may have more ruinous effects during service life of a structure in the case of being ignored. This side includes durability problems of structures. These problems may effect the structural stability and reliability day by day. Corrosion is one of durability problems concerned with the aggressive media having inverse effects on structures. Corrosion can be defined as deterioration of a material with chemical reactions resulting between the material and the aggressive media. The chemical reactions may occur on the surface of materials leading to the weight and section loss.

Corrosion is one of the most misunderstood and mischaracterized forms of material degradation. Consequently, corrosion analysis and mitigation methods tend to be some of the most misapplied. In many cases corrosion is the life-limiting factor of a structural component [1].

Corrosion problems can be met at any time during service life. Engineers must be ready for these undesirable conditions providing a good material selection and proper precaution methods. Thus, some production problems may occur during construction of structures comprising steel sections. Similar corrosion effects are studied in [2-9].

Nowadays, engineers face with associated pitfalls of corrosion. To decrease the destructive effects of corrosion reactions, some laboratory test methods must be performed to examine the service life performance of steel structural elements considering that apart from structures which extend some way into the splash zone, the results obtained from small-scale specimens are generally considered to be directly applicable to full-scale structures [5].The laboratory tests must simulate the almost real field conditions in order to determine exact results.

Corresponding author: A. U. OZTURK, e-mail: augurozturk@bayar.edu.tr 
Current laboratory tests and new required tests designed in the future bring capacities and knowledge desired in order to overcome corrosion and its destructive effects. Proper material selection and effective precaution methods as a result of good simulated tests are always necessary for structural stability and reliability.

Most of the laboratory experiments are about the marine environments that are recognized to be very corrosive for mild and low alloy steels. For economic reasons, such steels are still the preferred materials for offshore structures, ship hulls, sheet piling and harbor-side facilities [5]. Seawater, because of its variability is not easily simulated in the laboratory for corrosion-testing purposes. A $3.5 \% \mathrm{NaCl}$ solution is used frequently for this purpose and is known to be more aggressive toward carbon steel than natural seawater [10]. This indicates the importance, particularly for engineering design considerations, of understanding the factors that control immersion corrosion of steel as a function of water salinity. It was found that steel corroded nearly four times faster in a $3.5 \% \mathrm{NaCl}$ solution than in natural seawater for an exposure time of 21 days [11]. Corrosion resistance of mild steel samples varying with section types was determined. Aggressive media having destructive corrosion effects were formed by three different $\mathrm{NaCl}$ solutions $(3.5 \% ; 5.0 \%$ and $7.0 \%)$ and only distilled water. Corrosion rates and weight loss were determined at early ages such as 10;30; 60 and 90 days.

Experimental. The problem gets serious when corrosion effect on steel structures is seen by naked eye. To realize and determine the corrosion behavior of mild steel elements under aggressive media, three different section types according to section geometry were selected. Mild steel sample properties are given in Table 1. Density value for each section type is $7.85 \mathrm{~g} / \mathrm{cm}^{3}$.

Table 1. Mild steel sample characteristics

\begin{tabular}{|c|c|c|c|}
\hline Section type & Dimensions, $\mathrm{mm}$ & Initial weight, $\mathrm{g}$ & Surface area, $\mathrm{mm}^{2}$ \\
\hline & & & $50 \times 110 \times 40=22000$ \\
Box (B) & $50 \times 20 \times 110$ & 455.3 & $\begin{array}{c}46 \times 110 \times 40=20240 \\
\Sigma A=42240\end{array}$ \\
\hline & $\varnothing 60 \times 30 \times 110$ & 427.5 & $\begin{array}{c}\pi \times 60 \times 110=20735 \\
\pi \times 54 \times 110=18661 \\
\Sigma A=39396\end{array}$ \\
\hline Tube (C) & & & $50 \times 110 \times 20=11000$ \\
& & 399.5 & $\begin{array}{c}46 \times 110 \times 20=10120 \\
\Sigma A=21120\end{array}$ \\
\hline Corner (L) & $50 \times 50 \times 40-110$ & & \multicolumn{2}{|c}{} \\
& & &
\end{tabular}

Cycle activities were applied to observe the corrosion effect in the experimental part. Corrosion cycles include three different parts. First of all, mild steel samples were submerged into the $\mathrm{NaCl}$ solutions and distilled water in order to simulate an aggressive corrosion media during $12 \mathrm{~h}$. In the second part, samples were put into drying oven at $60^{\circ} \mathrm{C}$ for about thirty minutes. In the last part, cooling was performed in the laboratory conditions approximately between 20 and $22^{\circ} \mathrm{C}$. After that the weight losses in steel samples were measured to determine the corrosion rate. These corrosion cycles detailed below were repeated for 90 days.

The steel samples were subjected to corrosive media containing $\mathrm{NaCl}$ solutions with concentrations $0 \% ; 3.5 \% ; 5.0 \%$ and $7.0 \%$ respectively. The solution properties are given in Table 2. 
Table 2. Solution properties

\begin{tabular}{|c|c|c|c|}
\hline Solution & Initial solution & $\mathrm{NaCl}$ concentration, $\%$ & $\mathrm{pH}$ value \\
\hline Distilled water & $\mathrm{D}$ & 0 & 7.1 \\
\hline $3.5 \% \mathrm{NaCl}$ & $\mathrm{N} 3.5$ & 3.5 & 6.8 \\
\hline $5.0 \% \mathrm{NaCl}$ & $\mathrm{N} 5.0$ & 5.0 & 6.5 \\
\hline $7.0 \% \mathrm{NaCl}$ & $\mathrm{N} 7.0$ & 7.0 & 6.3 \\
\hline
\end{tabular}

All experiment sets were named with some initials. As an example, a set comprising tube steel samples and $5.0 \% \mathrm{NaCl}$ solution was named as "CN5". The symbols "C" and "N5" indicate section type (tube) and 5.0\% $\mathrm{NaCl}$ solution. There were $12 \mathrm{ex}$ periment sets including 9 samples as seen in Table 3.

Table 3. Experiment set definitions

\begin{tabular}{|l|c|}
\hline \multicolumn{1}{|c|}{ Experiment set definition } & Experiment set initial \\
\hline Box sections in distilled water & $\mathrm{BD}$ \\
\hline Tube sections in distilled water & $\mathrm{CD}$ \\
\hline Corner sections in distilled water & LD \\
\hline Box sections in $3.5 \% \mathrm{NaCl}$ solution & BN3.5 \\
\hline Box sections in $5.0 \% \mathrm{NaCl}$ solution & BN5 \\
\hline Box sections in $7.0 \% \mathrm{NaCl}$ solution & BN7 \\
\hline Tube sections in $3.5 \% \mathrm{NaCl}$ solution & $\mathrm{CN} 3.5$ \\
\hline Tube sections in $5.0 \% \mathrm{NaCl}$ solution & $\mathrm{CN} 5$ \\
\hline Tube sections in $7.0 \% \mathrm{NaCl}$ solution & $\mathrm{CN} 7$ \\
\hline Corner sections in $3.5 \% \mathrm{NaCl}$ solution & LN3.5 \\
\hline Corner sections in $5.0 \% \mathrm{NaCl}$ solution & LN5 \\
\hline Corner sections in $7.0 \% \mathrm{NaCl}$ solution & LN7 \\
\hline
\end{tabular}

Results and discussion. Corrosion effect is inevitable for steel structures and it can be minimized by taking early measurements. Thus, service life of a structure gets longer and less maintenance costs are needed.

Indeed, improper design and production of steel structures brings some durability and stability problems in service life. Corrosion negatively affects such structures. These structures lose their thickness, body symmetry and weight in the process of time. In addition corroded parts are responsible for density loss in the sections of steel structures.

Corrosion tests were done on steel samples to investigate the corrosion rate changing dependence on time and section type for different solution concentrations (Fig. 1). Weight losses increase in time according to corrosion process. Additionally the effect of section types on corrosion resistance was observed and maximum weight loss was see in box sections.

The minimum weight loss values were seen for samples submerged in distilled water, the maximum ones were obtained for samples in $7.0 \% \mathrm{NaCl}$ solutions. Similarly to Fig. 1 the section type effects on time varying corrosion ratios were investigated for mentioned solutions and the results are given in Fig. 2. 

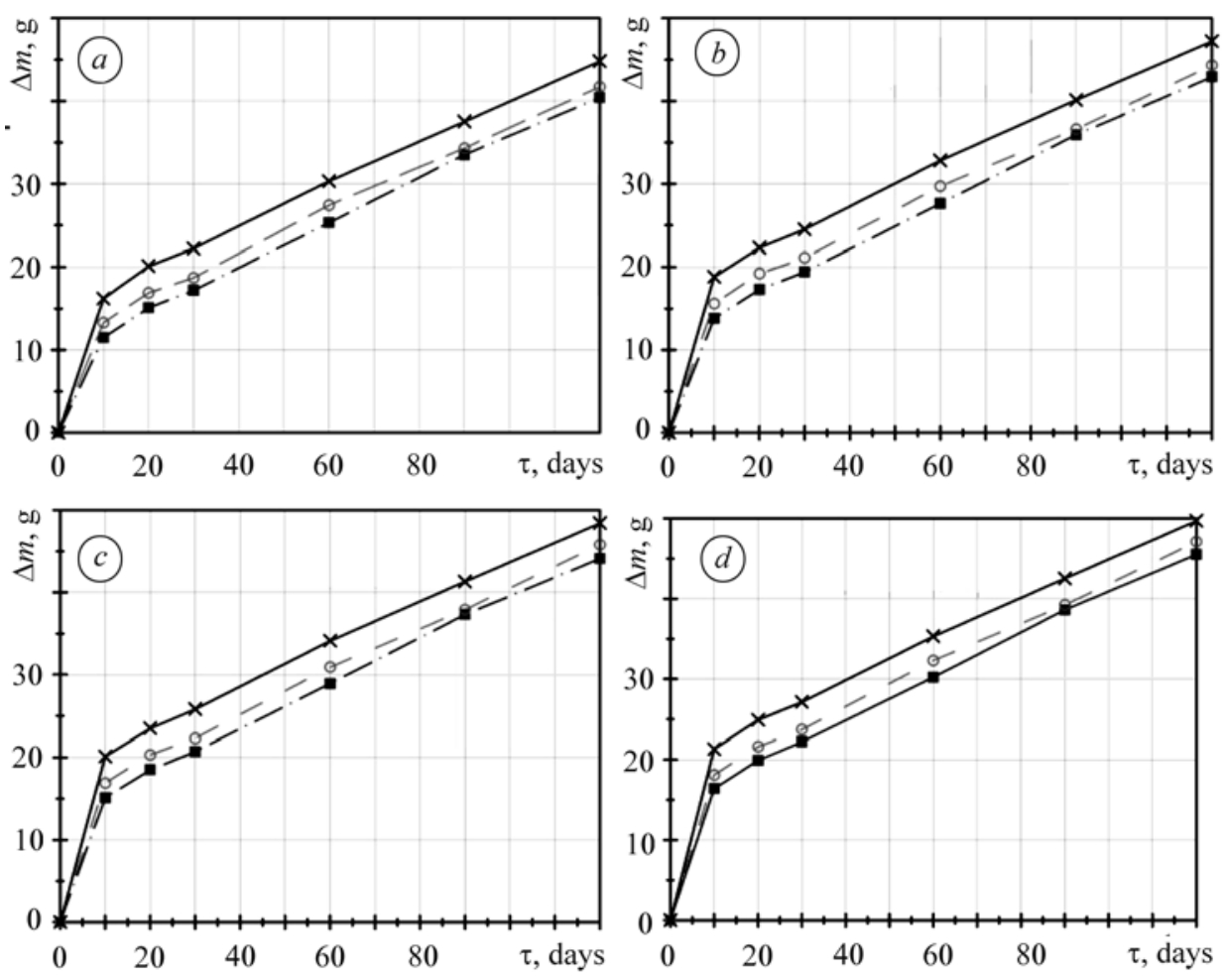

Fig. 1. Weight losses by time for different section types in: $a$-distilled water;

$b-3.5 \% \mathrm{NaCl} ; c-5.0 \% \mathrm{NaCl} ; d-7.0 \% \mathrm{NaCl}$. $\mathbf{\square}$ - corner; $\mathrm{O}$ - tube; $\times$ - box.
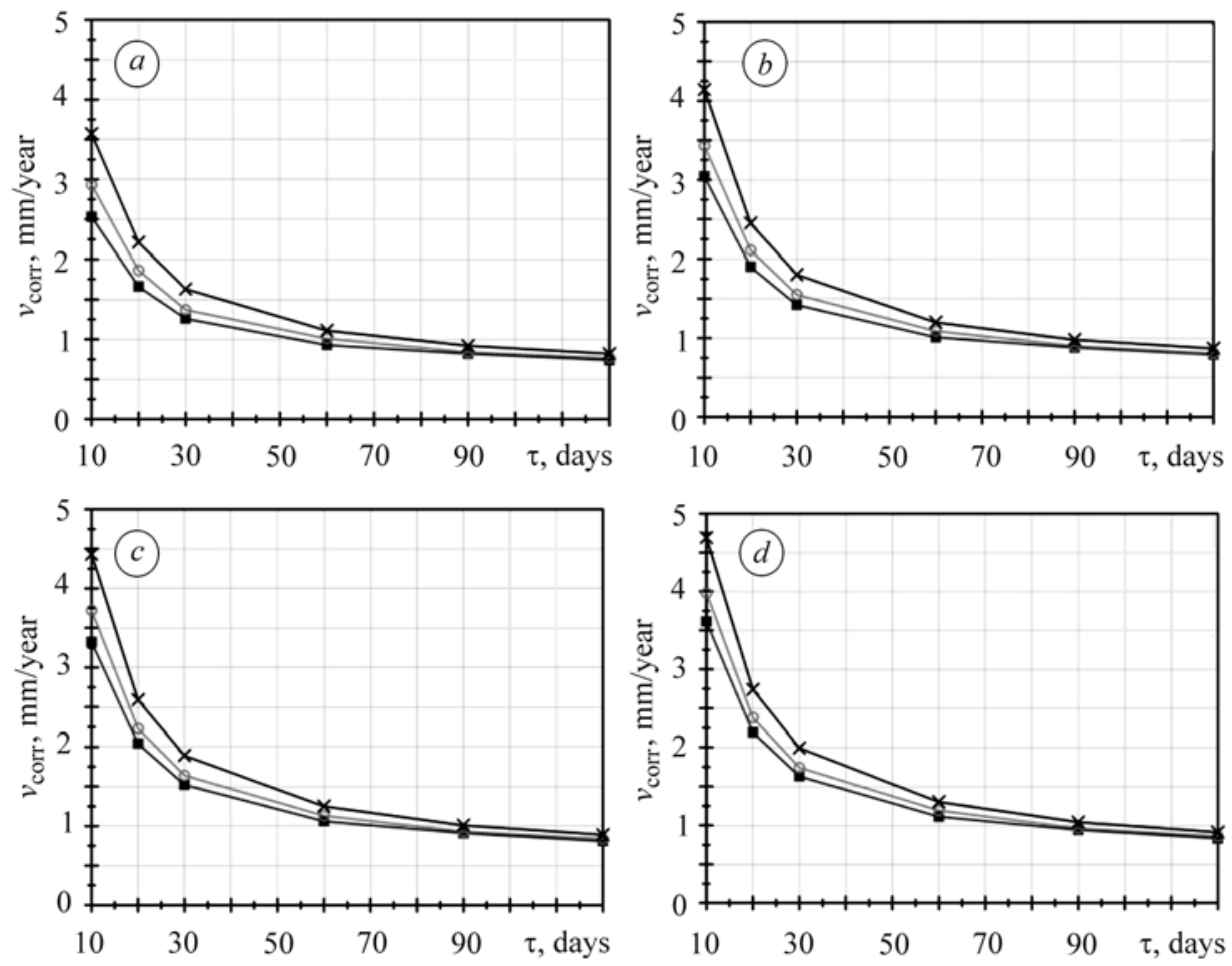

Fig. 2. Corrosion rates by time for different section types in: $a$-distilled water; $b-3.5 \% \mathrm{NaCl} ; c-5.0 \% \mathrm{NaCl} ; d-7.0 \% \mathrm{NaCl}$ - corner; $\mathrm{O}$ - tube; $\mathbf{X}$ - box. 
Although all $\mathrm{NaCl}$ solutions effect the corrosion in comparison with the distilled water, the solution concentration cannot present a distinctive effect on corrosion at the saturation limit. The effect of $7.0 \% \mathrm{NaCl}$ solution is almost the same as the effect of $5.0 \% \mathrm{NaCl}$ solution (Fig. 3).

The box sections were most affected by corrosion accordingly to both mass losses and corrosion rates. The solution effects on time varying corrosion rates were investigated for box sections as seen in Fig. 3. The solution effects on corrosion rate can be seen not only for box sections but also for all section types.

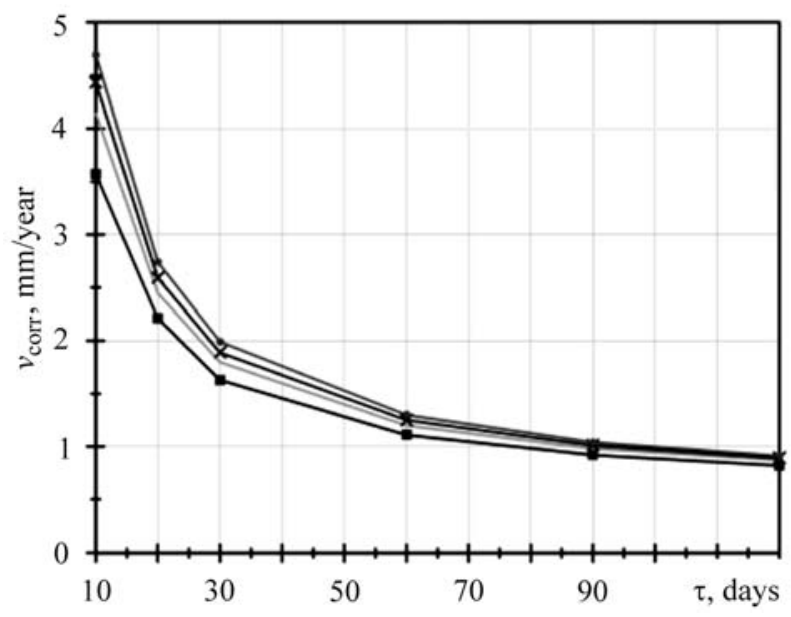

Fig. 3. Corrosion rates by time for box sections:

- distilled water; solid line $-3.5 \% \mathrm{NaCl} ; \times-5.0 \% \mathrm{NaCl} ;-7.0 \% \mathrm{NaCl}$.

\section{CONCLUSION}

Although it is easy to recognize corrosion of every steel construction detail, it is important to forecast its corrosion resistance before construction work. There are several methods to simulate the early age corrosion of steel details. Corrosion resistance of mild steel specimens with different sections types was investigated. Specimens were subjected to $\mathrm{NaCl}$ solutions of different concentration. Corrosion in distilled water was also taken into consideration. It was established that steel corrosion rate increases by solution concentration whereas decreases within the exposure time. The maximum corrosion rate values were obtained for box section samples. This study might be enhanced further by using different sections and solution concentration in different conditions.

РЕЗЮМЕ. Вивчено вплив тривалості експозиції, типу сталевого профілю та концентрації розчину на ранню стадію корозії вуглецевої сталі. Використано сталеві зразки у вигляді куба, трубки та кутника. Досліджували в 3,5-, 5,0- та 7,0\%-их розчинах $\mathrm{NaCl}$. Встановлено, що після досягнення граничної концентрації розчину хлориду натрію подальше збільшення вмісту солі не впливає на корозію сталі.

РЕЗЮМЕ. Изучено влияние продолжительности экспозиции, типа стального профиля и концентрации раствора на раннюю стадию коррозии углеродистой стали. Использованы стальные образцы в виде куба, трубки и угольника. Исследовали в 3,5-, 5,0- и 7,0\%-ых растворах $\mathrm{NaCl}$. Установлено, что после достижения предельной концентрации раствора хлорида натрия, последующее увеличение содержания соли не влияет на коррозию стали. 
1. Guthrie J., Battat B., and Grethlein C. Accelerated Corrosion Testing // The AMPTIAC Quarterly. - 2010.-6(3). - P. 11-15.

2. Melchers R. E. and Chernov B. B. Corrosion loss of mild steel in high temperature hard freshwater // Corr. Sci. - 2010. - 52, Issue 2. - P. 449-454.

3. Han L. and Song S. A measurement system based on electrochemical frequency modulation technique for monitoring the early corrosion of mild steel in seawater // Ibid. - 2008 . - 50, Issue 6. - P. 1551-1557.

4. Melchers R. E. Modelling immersion corrosion of structural steels in natural fresh and brackish waters // Ibid. - 2006. - 48, Issue 12. - P. 4174-4201.

5. Melchers R. E. Corrosion uncertainty modelling for steel structures // J. Constructional Steel Research. - 1999. - 52, Issue 1. - P. 3-19.

6. The inhibition of mild steel corrosion in acidic solutions by 2,5-bis(4-pyridyl)-1,3,4-thiadiazole: Structure-activity correlation / M. Lebrini, F. Bentiss, H. Vezin, and M. Lagrenée // Corr. Sci. - 2005. - 48, Issue 5. - P. 1279-1291.

7. Experimental and theoretical study for corrosion inhibition of mild steel in normal hydrochloric acid solution by some new macrocyclic polyether compounds / M. Lebrini, M. Lagrenée, H. Vezin, M. Traisnel, and F. Bentiss // Ibid. - 2007. - 49, Issue 5. - P. 2254-2269.

8. Corrosion behaviour of magnesium/aluminium alloys in $3.5 \mathrm{wt} . \% \mathrm{NaCl} / \mathrm{A}$. Pardo, M. C. Merino, A. E. Coy, V. Arrabal, F. Viejo, and E. Matykina // Ibid. - 2008. - 50, Issue 3. - P. 823-834.

9. Effect of ozone on corrosion behavior of mild steel in seawater / J. Liao, K. Kishimoto, M. Yao, Y. Mori, and M. Ikai // Ibid. - 2012. - 55, Issue 2. - P. 205-212.

10. Jones D. A. // Principles and Prevention of Corrosion. - Upper Saddle River. - NJ, Prentice Hall, 1996.

11. Möller H., Boshoff E. T., and Froneman H. // J. of the South African Institute of Mining and Metallurgy. - 2006. - 106. - P. 585-592. 